\title{
Haematological Parameters and Histopathological Alterations in the Gills of Fish, Catla catla Exposed to Azo Dye Acid Red -97
}

\author{
Avni I. Parmar*, Alkesh I. Shah \\ Department of Zoology B.P. Baria Science Institute, Navsari 396445, India
}

Received April 11, 2020; Revised May 4, 2020; Accepted June 16, 2020

Copyright $\bigcirc 2020$ by authors, all rights reserved. Authors agree that this article remains permanently open access under the terms of the Creative Commons Attribution License 4.0 International License

\begin{abstract}
Haematological and histopathological parameters have been recognized as valuable tools for monitoring fish health. This study was conducted to evaluate the chronic toxicity of Acid Red 97 textile dyes on haematological and histopathological alterations using Catla catla as animal model. Fish were exposed to two Sublethal concentrations $\left(1 / 100^{\text {th }}\right.$ and $1 / 50^{\text {th }}$ of $\mathrm{LC}_{50}=$ $85 \mathrm{mg} / \mathrm{l}) \quad 0.85 \mathrm{mg} / \mathrm{l}$ and $1.7 \mathrm{mg} / \mathrm{l}$ of AR 97 for a period of $(10,20$ and 30$)$ days. Haematological parameters were observed that with increase of exposure time, total erythrocyte (RBC), haemoglobin ( $\mathrm{Hb})$, and packed cell volume (PCV) values decreased but leucocytes (WBC), mean corpuscular hemoglobin concentration (MCHC), mean corpuscular volume (MCV) and mean corpuscular hemoglobin $(\mathrm{MCH})$ values increased. It is believed that observed depression in packed cell volume and haemoglobin values coupled with decreased and deformed erythrocytes are obvious signs of anemia. Resulted changes in erythrocytes and leukocytes after exposing to AR 97 are due to malfunction in hemopoiesis and decrease in non-specific immune system. Histopathological changes observed in the gills of Catla catla were swelling, aneurysm, fusion of lamellae, oedema in primary lamellae, shortened and severe erosions of secondary lamella and lifting epithelial layer and high mucus secretion. Hence, it was concluded that azo dye AR 97 has potential to cause toxicity in fish.
\end{abstract}

Keywords Acid Red 97, Catla catla, Dye, Haematology, Histopathology

\section{Introduction}

Most of the azo dyes are released into the environment originate from the textile industry and mainly from dyestuff manufacturing industry [1]. Approximately $10-15 \%$ dyes are released into the environment during dyeing process, making the effluent highly coloured and aesthetically unpleasant [2,3]. Textile azo dyes are serious pollutants of the aquatic environment because of their environmental persistence and ability to be accumulated by aquatic organism [4]. Fish can be considered as indicator organisms of environmental pollution [5-7]. This is because they are constantly exposed to toxic elements dissolved in water, through gill breathing and epidermis contact [8,9]. Haematological parameters are patho-physiological reflectors of the whole fish body. Moreover, these blood parameters are too sensitive to any physicochemical, biological and/or environmental alterations. Hence, they are important markers to investigate the structural and functional status of fish exposed to various contaminants $[10,11]$.

Histological changes have been widely used as biomarkers in the evaluation of health of fish exposed to contaminants both in the laboratory [12] and field studies $[13,14]$. Thus the present study deals with the chronic toxic effect of Acid red 97 on a freshwater fish Catla catla with the objective to study the haematological and histological alterations on the treated gill tissues for 10, 20 and 30 days.

\section{Materials and Methods}

\subsection{Experimental Design}

AR 97 was purchased from local market and used directly for the experiment. Catla catla fingerlings ( $13 \pm 1 \mathrm{~cm}$ long and $25 \pm 2.5 \mathrm{~g}$ weight) were procured from fish seed farm sivan, surat, Gujarat and acclimatized in the 
laboratory condition for 15 days according to APHA [15]. After acclimatization, apparently healthy catla fingerlings were grouped in to 4 (10 in each) and used to carry out toxicity test. Among this one was considered as control and other 3 groups of catla fingerlings were exposed to sublethal concentration 0.85 and $1.7 \mathrm{mg} / 1\left(1 / 100^{\text {th }}\right.$ and $1 / 50^{\text {th }}$ of $\left.\mathrm{LC}_{50}=85 \mathrm{mg} / \mathrm{l}\right)$ of AR 97 for 30 days in triplicates. At fixed interval (10, 20, 30 days) after the exposure blood samples were collected and were analyzed.

\subsection{Haematological Studies}

Blood was collected by direct puncturing heart and/or caudal vein using sterile syringe $(2 \mathrm{ml})$ pre-rinsed with $2.7 \%$ EDTA solution. Collected blood samples were immediately transferred to vials $(2 \mathrm{ml})$ coated with EDTA. Haemoglobin estimation was done by cyanmethemoglobin method [16]. $20 \mu \mathrm{l}$ of blood samples were taken in Thoma's pipettes. They were mixed with diluting fluids Turks' solution for WBC count and Haem solution for RBC count in the same pipettes. The mixtures were shaken well to suspend cells uniformly in solution. After 10 to 15 minutes, cells were counted using haemocytometer [17].

\subsection{Statistical Analysis}

Statistical analyses were calculated in triplicate performed using the computer software 'SPSS'. Data are presented as mean $\pm \mathrm{SD}$. The significant means were compared to control and a $\mathrm{p}<0.05$ was considered to be the level of statistically significant.

\subsection{Histopathological Studies}

The fishes were exposed to both sub lethal concentrations of dyes and at the end of 10,20 and 30 day exposure period gills were dissected out and fixed in $10 \%$ buffered formalin. The tissues were then processed in ascending order of alcohol for dehydration, embedded in paraffin wax and sectioned at $5-6 \mu \mathrm{m}$ on a rotary microtome. Sections were placed on glass slides and stained with haematoxylin and eosin [18]. Approximately 5-6 stained slides were examined with the help of a compound microscope and photographs were taken. Histopathological changes in these tissues were recorded and compared with controls under the guidance of a pathologist.

\section{Results}

\subsection{Haematological Parameters}

Fingerlings exposed to the low concentration $(0.85 \mathrm{mg} / \mathrm{l})$ of AR 97 azo dye showed decreased haemoglobin level and RBC count where WBC counts were increased. Similarly, the same trends were reported throughout the exposure at 10, 20 and 30 days. When blood sample collected from $(1.7 \mathrm{mg} / \mathrm{l})$ exposed fingerlings, also showed similar trend of decreasing in case of $\mathrm{RBC}$ and $\mathrm{Hb}$ and increasing WBC count throughout the exposure. In short, total RBC count and haemoglobin were decreased but WBC count was continuously increased throughout the exposure in both sublethal concentrations (Bar graph 1-3). All observations and results of AR 97 exposed fingerlings are summarized in the (Table 1). Statistical analysis indicates that all the values were significant.

Table 1. Effect of AR 97 on haematological parameters

\begin{tabular}{|c|c|c|c|c|}
\hline $\begin{array}{c}\text { Sublethal Concentrations } \\
\text { of AR } 97\end{array}$ & $\begin{array}{l}\text { Exposure } \\
\text { (Days) }\end{array}$ & & Blood paramet & \\
\hline & & $\mathrm{Hb}(g / d l)$ & $\begin{array}{c}\text { RBC count } \\
\left(10^{6} \text { cells } / \mathrm{mm}^{3}\right)\end{array}$ & $\begin{array}{c}\text { WBC count } \\
\left(10^{6} \text { cells } / \mathrm{mm}^{3}\right)\end{array}$ \\
\hline & $\mathbf{0}$ & $6.47 \pm 0.03$ & $2.42 \pm 0.15$ & $1.86 \pm 0.05$ \\
\hline \multirow{3}{*}{$0.85 \mathrm{mg} / \mathrm{l}$} & 10 & $6.34 \pm 0.18^{*}$ & $2.32 \pm 0.09 *$ & $2.01 \pm 0.12 *$ \\
\hline & 20 & $6.07 \pm 0.07 *$ & $2.00 \pm 0.10^{*}$ & $2.18 \pm 0.09^{*}$ \\
\hline & 30 & $5.88 \pm 0.12^{*}$ & $1.92 \pm 0.08^{*}$ & $2.53 \pm 0.04 *$ \\
\hline \multirow{3}{*}{$1.7 \mathrm{mg} / \mathrm{l}$} & 10 & $5.96 \pm 0.07^{*}$ & $2.11 \pm 0.06^{*}$ & $2.31 \pm 0.04 *$ \\
\hline & 20 & $5.80 \pm 0.07^{*}$ & $1.89 \pm 0.07 *$ & $2.46 \pm 0.12 *$ \\
\hline & 30 & $5.43 \pm 0.09 *$ & $1.59 \pm 0.12 *$ & $3.06 \pm 0.09 *$ \\
\hline
\end{tabular}

[Each value is mean $\pm \mathrm{SE}$ of thirty individual observations; Asterisks $(*)$ indicate significant $(\mathrm{p}<0.05)$ difference compared to control.] 


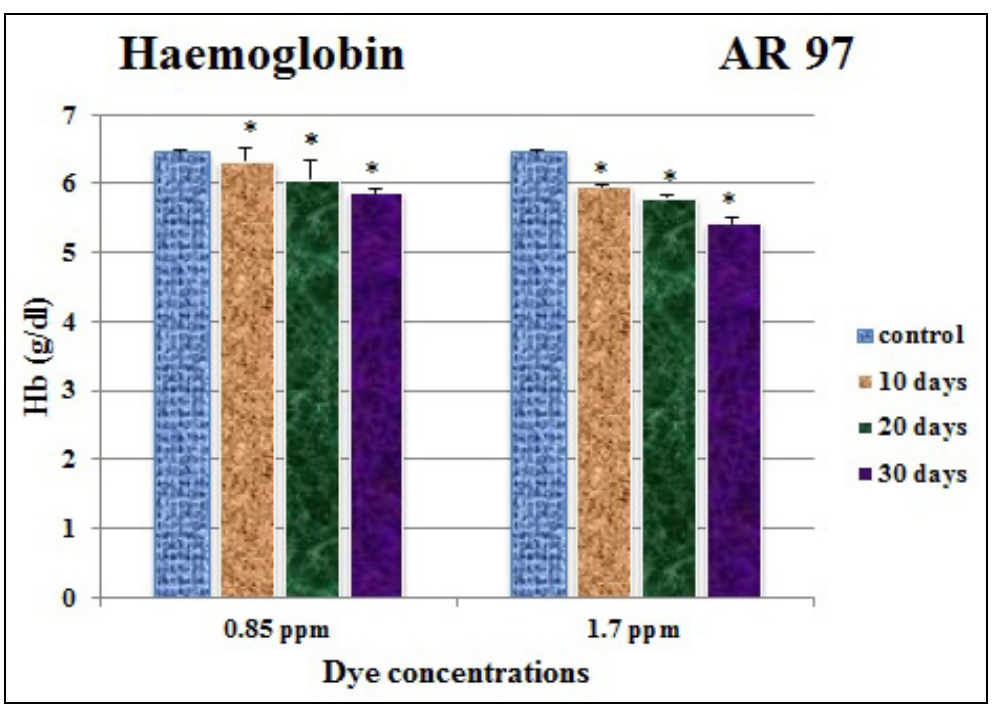

Bar graph 1. Level of haemoglobin in Catla catla

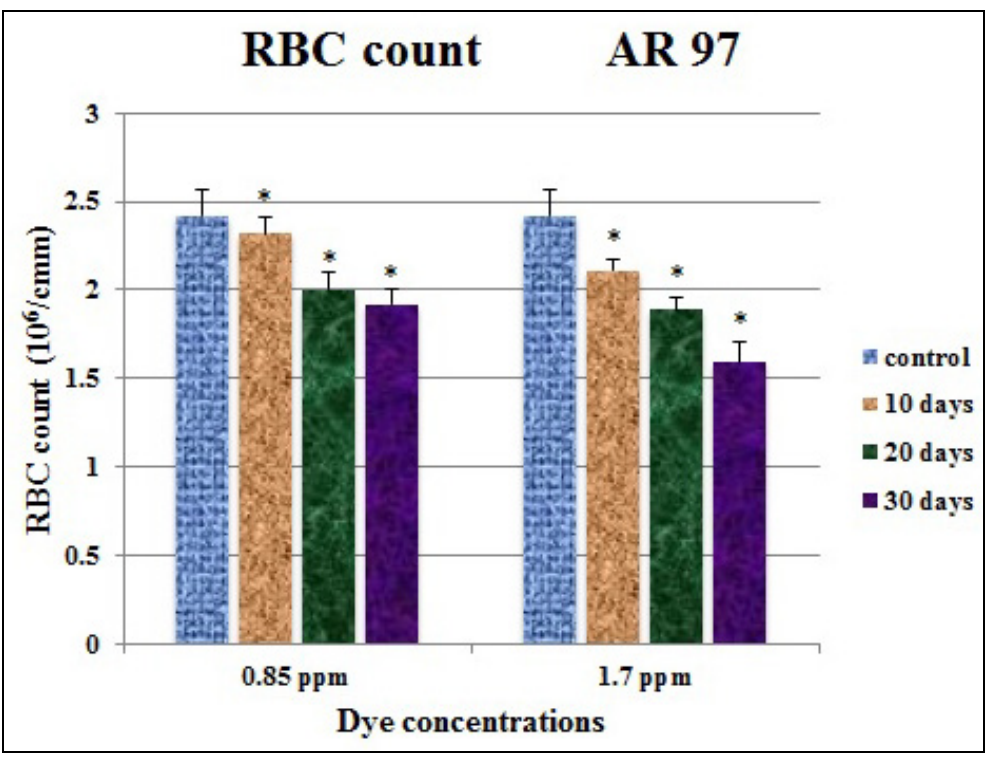

Bar graph 2. RBC count in Catla catla

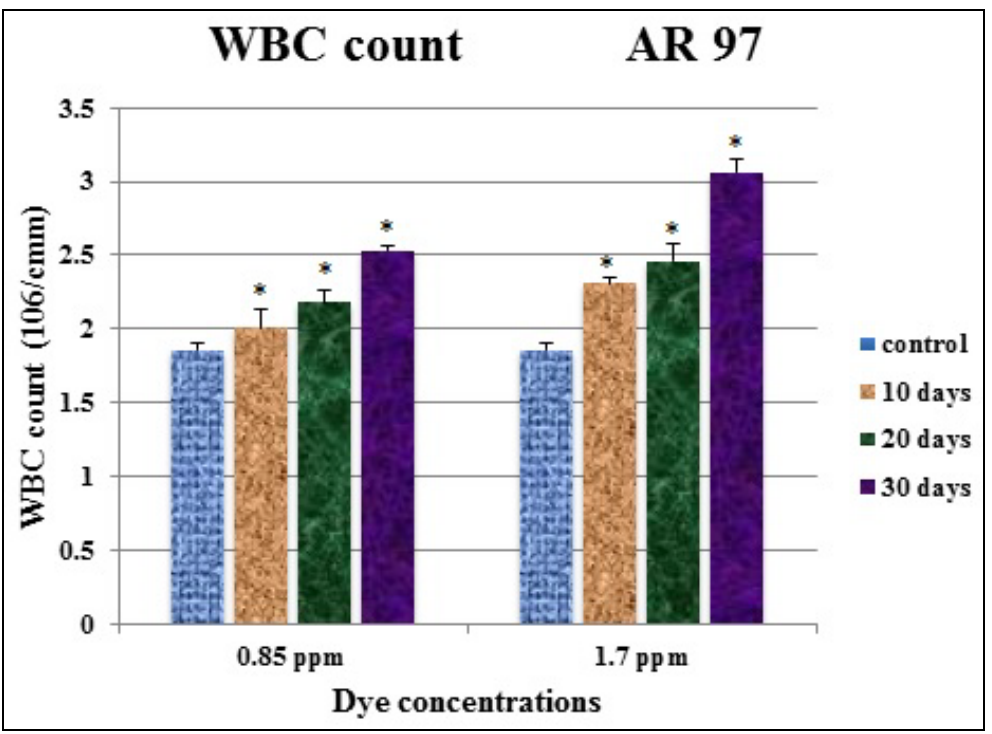

Bar graph 3. WBC count in Catla catla 
Haematological indices like PCV, MCV, MCH and MCHC were calculated from obtained results of haemoglobin and RBC value of blood samples collected from control as well as exposed fingerlings. The blood sample collected from the fingerlings exposed to AR 97, showed decreased value of PCV throughout the experiment (Bar graph 4). The $\mathrm{MCV}$ and $\mathrm{MCH}$ both showed the increased value during the whole exposure period for both sublethal concentrations (Bar graph 5,6). The similar increasing trend was also noticed for MCHC (Bar graph 7). Obtained results are summarized in the Table 2.

Table 2. Effect of AR 97 on haematological indices

\begin{tabular}{|c|c|c|c|c|c|}
\hline $\begin{array}{c}\text { Sublethal } \\
\begin{array}{c}\text { Concentrations of AR } \\
\mathbf{9 7}\end{array}\end{array}$ & $\begin{array}{c}\text { Exposure } \\
\text { (Days) }\end{array}$ & \multicolumn{4}{|c|}{ Haematological indices } \\
\hline & & PCV \% & MCV (fl) & MCH(pg) & MCHC \% \\
\hline \multirow{3}{*}{$\mathbf{0 . 8 5} \mathbf{~ p p m}$} & $\mathbf{0}$ & $24.84 \pm 0.09$ & $102.64 \pm 0.10$ & $26.73 \pm 0.12$ & $26.06 \pm 0.11$ \\
\cline { 2 - 6 } & $\mathbf{1 0}$ & $23.92 \pm 0.10^{*}$ & $103.10 \pm 0.11^{*}$ & $27.32 \pm 0.20^{*}$ & $26.50 \pm 0.07^{*}$ \\
\cline { 2 - 6 } & $\mathbf{2 0}$ & $20.78 \pm 0.06^{*}$ & $103.90 \pm 0.09^{*}$ & $30.35 \pm 0.13^{*}$ & $28.93 \pm 0.09^{*}$ \\
\hline \multirow{3}{*}{$\mathbf{1 . 7} \mathbf{p p m}$} & $\mathbf{3 0}$ & $19.99 \pm 0.09^{*}$ & $104.11 \pm 0.12^{*}$ & $30.92 \pm 0.09^{*}$ & $29.42 \pm 0.22^{*}$ \\
\cline { 2 - 6 } & $\mathbf{1 0}$ & $22.04 \pm 0.04^{*}$ & $104.45 \pm 0.07^{*}$ & $28.24 \pm 0.13^{*}$ & $27.04 \pm 0.10^{*}$ \\
\cline { 2 - 6 } & $\mathbf{3 0}$ & $16.91 \pm 0.06^{*}$ & $106.35 \pm 0.13^{*}$ & $34.15 \pm 0.08^{*}$ & $32.11 \pm 0.13^{*}$ \\
\hline
\end{tabular}

[Each value is mean $\pm \mathrm{SE}$ of thirty individual observations; Asterisks $\left(^{*}\right)$ indicate significant $(\mathrm{p}<0.05)$ difference compared to control.]

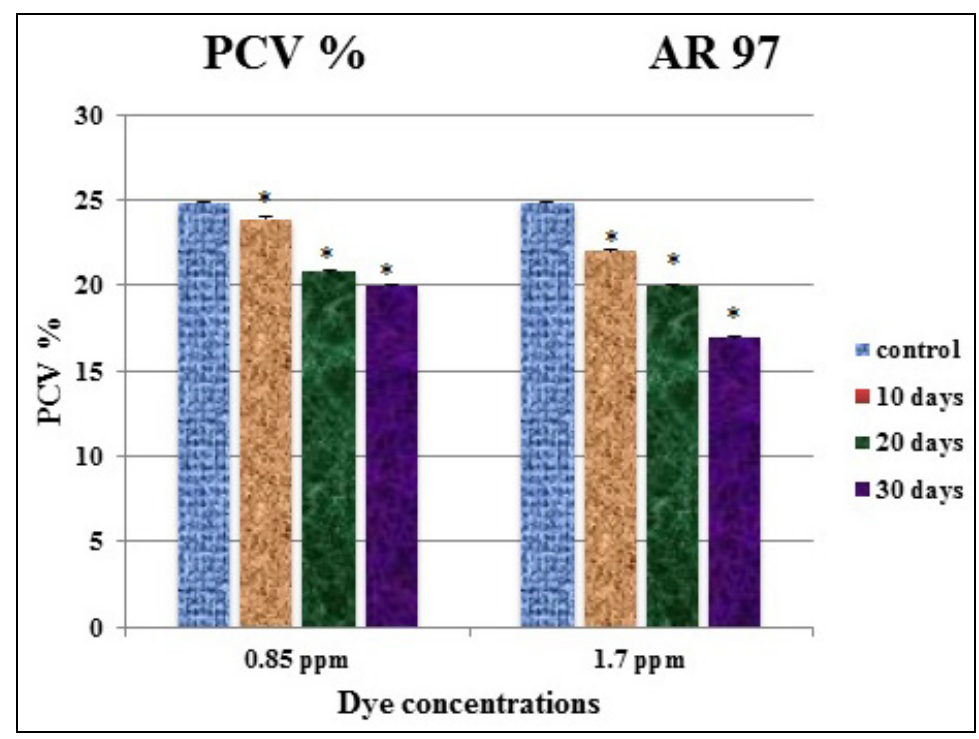

Bar graph 4. Level of PCV in Catla catla 


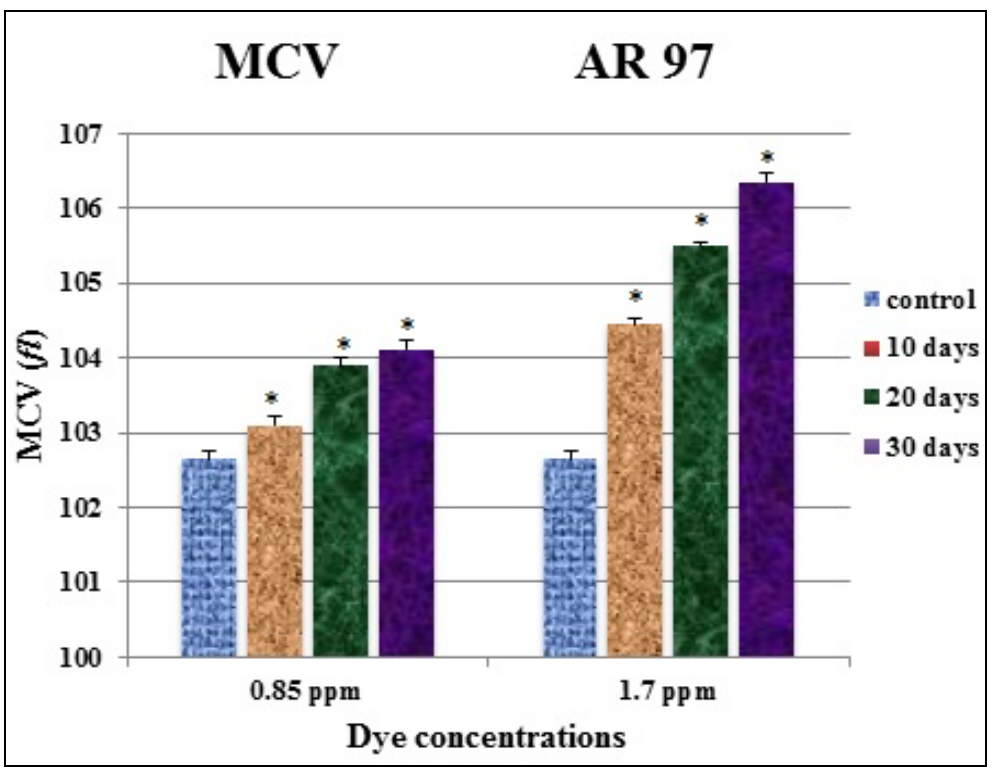

Bar graph 5. Level of MCV in Catla catla

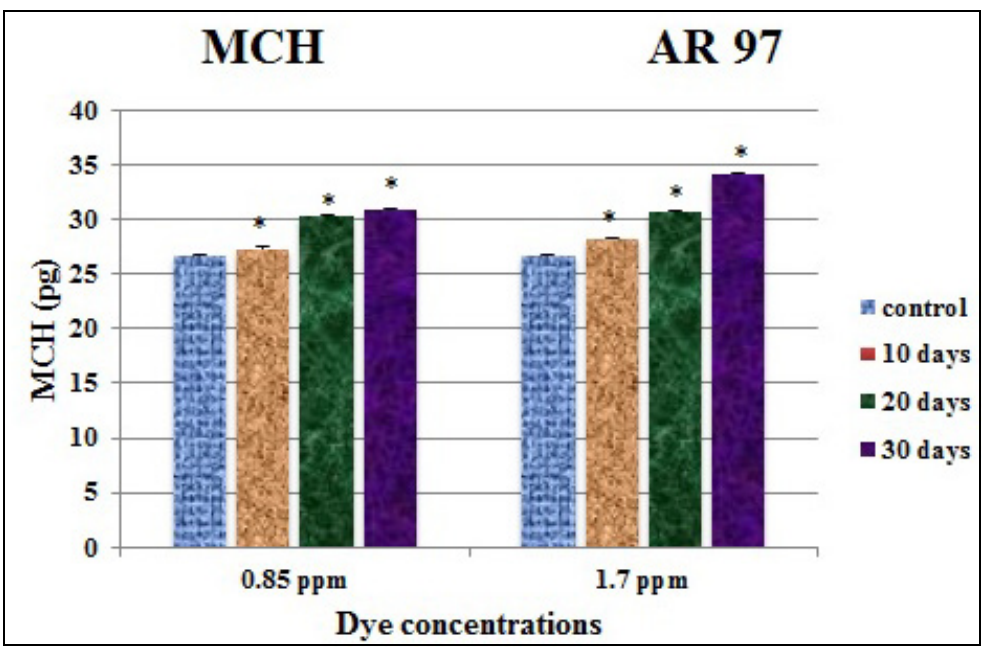

Bar graph 6. Level of $\mathrm{MCH}$ in Catla catla

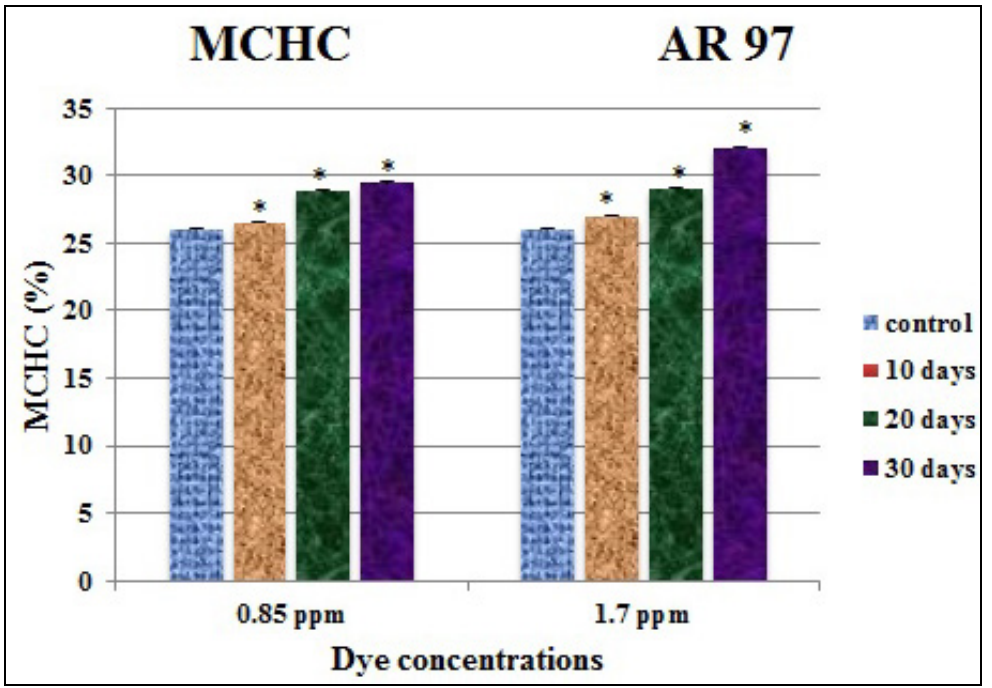

Bar graph 7. Level of MCHC in Catla catla 


\subsection{Histopathology of Gills}

Primary gill lamellae have rows of secondary gill lamellae ideally arranged and lined up on both sides. The typical histological pattern in secondary lamellae of the normal gill is shown in control. The epithelial cell line covers both primary and secondary gill lamellae. As the gills are the first target organ for any toxicant, they are affected maximally. Many histological changes were observed in gill of exposed fingerlings. These changes were concentration as well as time dependent. After exposure to both $(0.85$ and $1.7 \mathrm{mg} / \mathrm{l})$ sublethal concentrations of AR 97, gills showed mild to severe haemorrhage at the axis of primary gill lamellae. Extensive hyperplasia of chloride cells at the base of the gill filament and secondary lamellae were common observations in both concentrations in at 10,20 and 30 days. After 10 days exposer of $0.85 \mathrm{mg} / 1$ concentration to fingerlings showed histological alteration in gills like oedema in primary lamella, shorted secondary lamella, lamellar fusion, epithelial lifting and mild degeneration of central axis (Fig.1/B). After 20 days erosion of secondary lamella and mild hemorrhage in primary lamella were started also shown oedema in primary lamella, shorted secondary lamella, lamellar fusion (Fig.1/C). After 30 days showed aneurysm, complete erosion of secondary lamella and hemorrhage in primary lamella (Fig.1/D).

At $1.7 \mathrm{mg} / \mathrm{l}$ of concentrations, fingerling showed Oedema of the primary gill lamella, disorganization of central axis and epithelial lifting along with erosion of secondary lamella were observed during 10 days of exposure (Fig.2/B). Severe haemorrhage at the axis of the primary gill lamellae, shortened, erosion and curling of secondary lamella along with the minute epithelial lifting from the lamellae and aneurysm were observed after 20 days of exposure (Fig.2/C). In some portions, the gills also showed aneurysm and degeneration of central axis disorganization of the tissue and complete erosion of secondary gill lamellae and mild hemorrhagic tip of the primary gill lamellae at the end of exposures at 30 days (Fig.2/D).

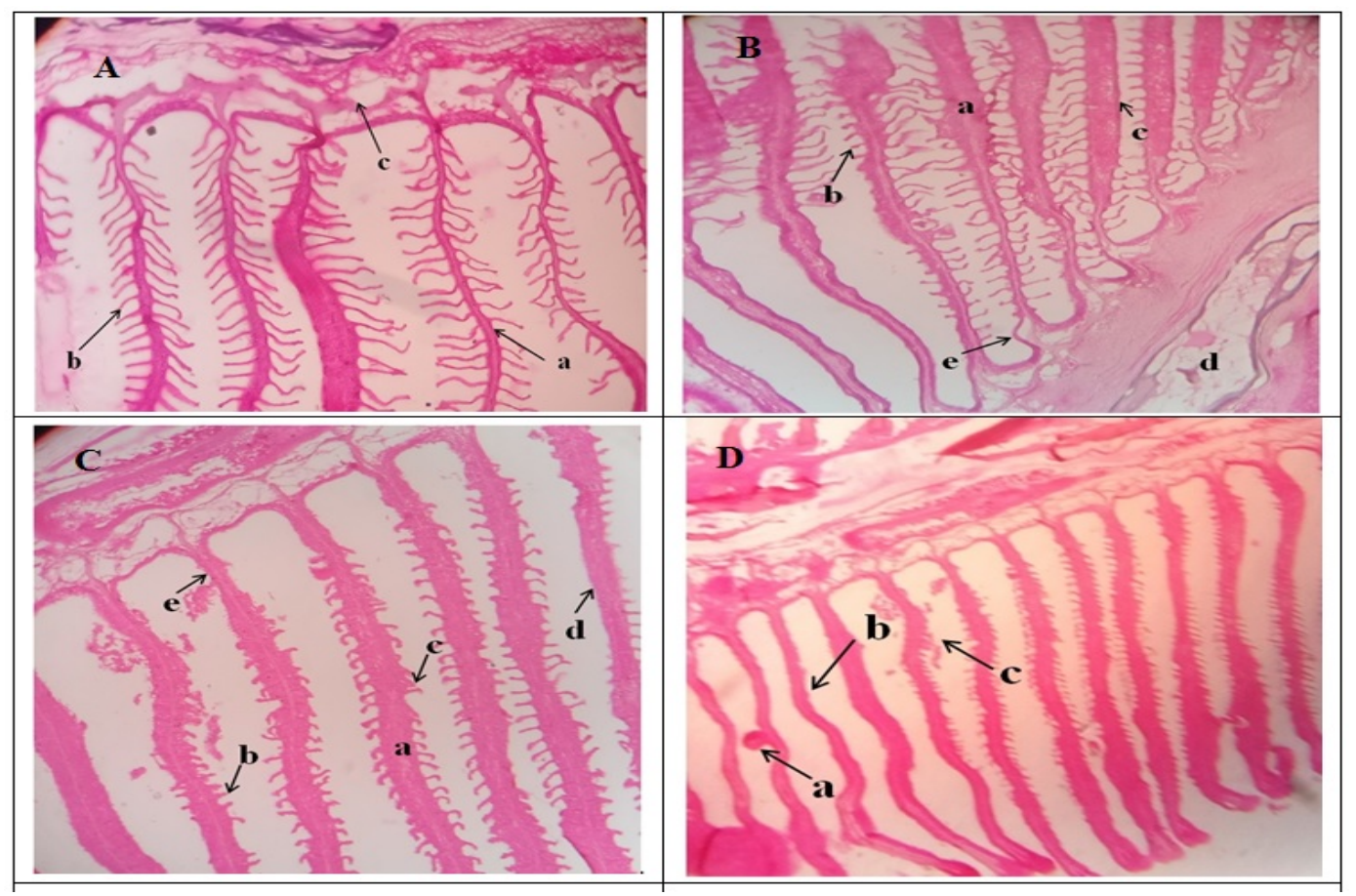

Figure 1. Effect of AR 97 exposed to $0.85 \mathrm{mg} / \mathrm{l}$ on the structure of gills on Catla catla by photomicrograph [A] Control: Normal gill (a) primary lamella (b) secondary lamella (c) central axis [B] 10 days (a) oedema in primary lamella (b) shorten secondary lamella (c) lamellar fusion (d) mild degeneration of central axis (e) epithelial lifting [C] 20days (a) oedema in primary lamella (b) shorten secondary lamella (c) lamellar fusion (d) erosion of secondary lamella (e) hemorrhagic primary lamella[D] 30days (a) aneurysm (b) complete erosion of secondary lamella (c) hemorrhagic primary lamella 


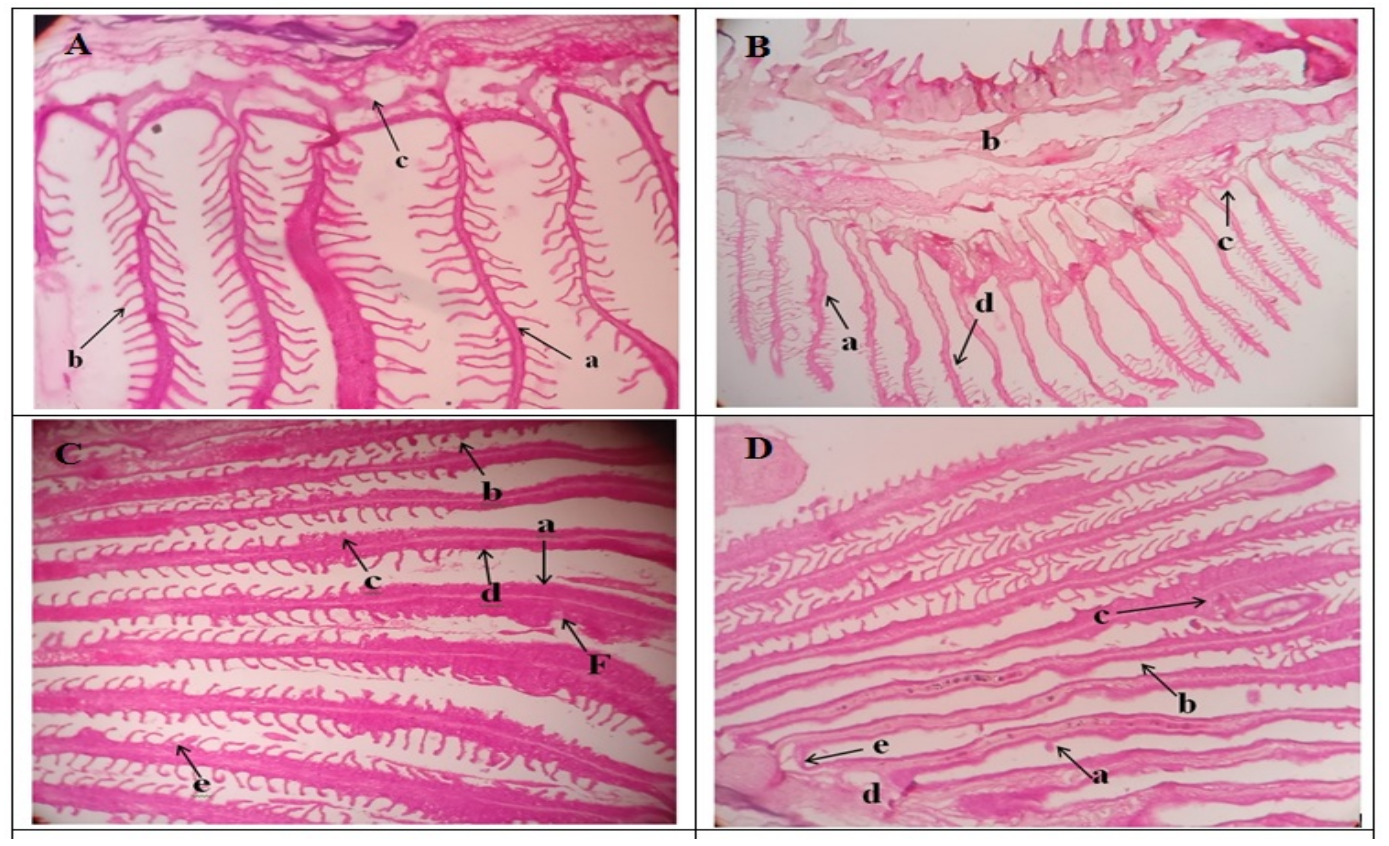

Figure 2. Effect of AR 97 exposed to $1.7 \mathrm{mg} / \mathrm{l}$ on the structure of gills on Catla catla by photomicrograph[A] Control: Normal gill (a) primary lamella (b) secondary lamella (c) central axis [B] for 10days (a) oedema in primary lamella (b) disorganization of central axis(c) epithelial lifting (d) erosion of secondary lamella [C] for 20days (a) oedema in primary lamella (b) shorten secondary lamella (c) lamellar fusion (d) erosion of secondary lamella (e) curling of secondary lamella (f) hemorrhagic primary lamella [D] for 30days (a) aneurysm (b) complete erosion of secondary lamella (c) hemorrhagic primary lamella (d) degeneration of central axis (e) epithelial lifting

\section{Discussion}

Results obtained from this study show significantly decreased $\mathrm{Hb}$ content and $\mathrm{RBC}$ count as compared to control. On the other hand, WBC count increased in all AR 97 exposed fingerlings. It clearly indicates the toxic potential of AR 97 even at sublethal concentrations that affect the haemato-physiology of exposed fingerlings. All mentioned alterations indicate that exposed fingerlings suffered from anemia induced by dye. This is an indication of disruptive effects of azo dyes on erythropoietic tissues as well as cells viability [19]. Our previous study also supports the results of the present study [20]. Significant decrease in haemoglobin has been reported in Clarias batrachus by Patnaik and Patra an exposed to sublethal concentration of propoxur and carbaryl [21]. Similar decrease found in Carassius auratus gibelio when they were exposed to the toxic textile dye [22]. Changes in haematological parameters of Heteropneustes fossilis has been supported our results when the exposed to galvanizing industry effluent [23].

When fingerling Catla catla were exposed to dye AR 97 total count of RBC's reduced compare to control. Alterations in RBC count exposed to various toxicants have been reported by many researchers [24,25]. Significant reduction in RBC count was noted in cypermethrin treated Labeo rohita [26] and in freshwater Cyprinus carpio treated with diazinon [27]. Decrease in the value of $\mathrm{Hb}, \mathrm{PCV}, \mathrm{RBCs}$ may results in hypochromic microcytic anemia which may be due to deficiency of iron and its decreased utility [28]. In the present study, WBC count increased following exposed dye AR 97. Significant increase was also observed in the total WBC count after exposure to malachite green and Pyceze [29]. WBC plays a major role in the defense mechanism of fish. In other words, an immediate activation of the fish immune system is proved by increase in leucocytes [30]. A rise in WBC count following exposure to insecticides has been also reported [31].

Red blood cells indices $\mathrm{MCV}, \mathrm{MCH}$, and $\mathrm{MCHC}$ are often determined as an index of health status especially in aquatic organisms [32]. In the present study, rise in MCV values seems to be correlated with decline in $\mathrm{RBC}$ count. A significant increase in MCV values was also observed in malachite green exposed fish [33,34]. Likewise significantly increased MCHC and MCH level was also noticed in European catfish (Silurus glanis L.) exposed to organophosphorous insecticide, diazinon and koprucu et al. in Salmo salar exposed to endosulfan $[35,36]$.

The gills are among the most vulnerable structures of the teleost fish because of their external location and intimate contact with the water. So, they are liable to damage by any irritant materials whether dissolved or suspended in the water [18]. Oedema and epithelial lifting are the results of defense mechanism. As the distance of the lamellar epithelium increases from the secondary gill lamellae, it prevents the direct diffusion of the toxicant present in the water body. These kinds of histological 
changes in the gills have been observed by researchers due to toxic effects of copper [37].

The gills, which participate in many important functions in the fish, such as respiration, osmoregulation and excretion, remain in close contact with the external environment and particularly sensitive to changes in the quality of the water are considered the primary target of the contaminants [38]. Haemorrhage in gills was also observed in Gambusia affinis and Clarias gariepinus exposed to textile effluents and herbicide [39,40]. Ribeiro et al. observed proliferation of epithelial cells and fusion between the secondary lamellae in Salvelinus alpines exposed inorganic mercury and methyl mercury [41].

Most common changes like epithelial lifting, oedema, lamellar fusion, collapsed secondary lamellae and curling of secondary lamellae have been reported by Velmurugan et al. and Jiraungkoorskul et al. in Cirrhinus mrigala and Oreochromis niloticus exposed to pesticide and herbicide $[42,43]$.

\section{Acknowledgements}

One of the authors, Avni parmar Ph.D. Scholar is very grateful to UGC Rajiv Gandhi National Fellowship for financial support.

\section{REFERENCES}

[1] Carliell CM, Barclay SJ, Naidoo N, Buckley CA, Mulholland DA, Senior E. Microbial decolourisation of a reactive azo dye under anaerobic conditions. Water Sa. 1995; 21(1):61-9.

[2] Weber EJ, Adams RL. Chemical-and sediment-mediated reduction of the azo dye disperse blue 79 . Environmental science \& technology. 1995; 29(5):1163-70.

[3] Padhi BS. Pollution due to synthetic dyes toxicity \& carcinogenicity studies and remediation. International Journal of Environmental Sciences. 2012; 3(3):940-55.

[4] Saratale RG, Saratale GD, Chang JS, Govindwar SP. Bacterial decolorization and degradation of azo dyes: a review. Journal of the Taiwan Institute of Chemical Engineers. 2011; 42(1):138-57.

[5] Metcalfe - Smith JL, Holtze KE, Sirota GR, Reid JJ, de Solla SR. Toxicity of aqueous and sediment - associated fluoride to freshwater organisms. Environmental Toxicology and Chemistry: An International Journal. 2003; 22(1):161-6.

[6] Bhatnagar C, Regar BC. Neurodegenerative effect of fluoride (naf) on the brain of freshwater teleost, labeorohita. Indian Journal of Environmental Sciences. 2005; 9(1):15-9.

[7] Bhatnagar C, Bhatnagar M, Regar BC. Fluoride-induced histopathological changes in gill, kidney, and intestine of fresh water teleost, Labeo rohita. Fluoride. 2007; 40(1):55-61.

[8] Gernhöfer M, Pawert M, Schramm M, Müller E, Triebskorn R. Ultrastructural biomarkers as tools to characterize the health status of fish in contaminated streams. Journal of Aquatic Ecosystem Stress and Recovery. 2001; 8(3-4):241-60.

[9] Bears H, Richards JG, Schulte PM. Arsenic exposure alters hepatic arsenic species composition and stress-mediated gene expression in the common killifish (Fundulus heteroclitus). Aquatic toxicology. 2006; 77(3):257-66.

[10] Adhikari S, Sarkar B, Chatterjee A, Mahapatra CT, Ayyappan S. Effects of cypermethrin and carbofuran on certain hematological parameters and prediction of their recovery in a freshwater teleost, Labeo rohita (Hamilton). Ecotoxicology and Environmental safety. 2004; 58(2):220-6.

[11] Parmar A. and Barot J. Haematotoxic potential of Acid Red 97 on Catla catla (Ham.). Bioscience Discovery. 2017; $8(2): 198-201$

[12] Wester PW, Canton JH. The usefulness of histopathology in aquatic toxicity studies. Comparative biochemistry and physiology. C, Comparative pharmacology and toxicology. $1991 ; 100(1-2): 115-7$.

[13] Schwaiger J, Wanke R, Adam S, Pawert M, Honnen W, Triebskorn R. The use of histopathological indicators to evaluate contaminant-related stress in fish. Journal of Aquatic Ecosystem Stress and Recovery. 1997; 6(1):75-86.

[14] Teh SJ, Adams SM, Hinton DE. Histopathologic biomarkers in feral freshwater fish populations exposed to different types of contaminant stress. Aquatic toxicology. 1997; 37(1):51-70.

[15] APHA. Standard methods for the examination of water and waste water. 21st Ed. Washington, DC, 2005.

[16] Dacie JA and Lewis SM. Practical haematology (4th ed.).J and A Churchill, U.K., 37, 1968.

[17] Schalm OW, Jain NC and Carrolt EJ.Veterinary haematology 3rd, Lea and Febiger Philadelphia. 1975; 324-335.

[18] Roberts RJ, Richards RH. The Bacteriology of Teleost in Fish Pathology. Bailliere Tindal Book Publ, London. 1978.

[19] Sudakov KV. Stress: postulates, analysis in terms of the general theory of functional systems. Patologicheskaia fiziologiia i eksperimental'naia terapiia. 1992; (4):86-93.

[20] Parmar A, Barot J. Determination of genotoxic effect of azo dye CI RR 120 on fish Catla catla. Biotechnological Research. 2016; 2(2):77-80.

[21] Patnaik L, Patra AK. Haemoatopoietic alterations induced by carbaryl in Clarias batrachus (LINN). Journal of Applied Sciences and Environmental Management. 2006;10(3):5-7.

[22] Al-Sabti K. Chlorotriazine reactive azo red 120 textile dye induces micronuclei in fish. Ecotoxicology and Environmental Safety. 2000; 47(2):149-55.

[23] Majumdar AS, Saraf MN, Kamble RY. Antioxidant activity of Eclipta alba L. in normal rat liver. Iranian Journal of 
Pharmacology and Therapeutics. 2010; 9(2):103-105.

[24] Sampath K, James R, Velammal S. Effect of methyl parathion on blood parameters and its recovery in a catfish, Mystus keletius. Indian journal of fisheries. 2003; 50(2):191-7.

[25] Parma MJ, Loteste A, Campana M, Bacchetta C. Changes of hematological parameters in Prochilodus lineatus(Pisces, Prochilodontidae) exposed to sublethal concentration of cypermethrin. Journal of Environmental Biology. 2007; 28(1):147-9.

[26] Das BK, Mukherjee SC. Toxicity of cypermethrin in Labeo rohita fingerlings: biochemical, enzymatic and haematological consequences. Comparative Biochemistry and Physiology Part C: Toxicology \& Pharmacology. 2003; 134(1):109-21.

[27] Svoboda M, Luskova V, Drastichova J, Žlabek V. The effect of diazinon on haematological indices of common carp (Cyprinus carpio L.). Acta Veterinaria Brno. 2001; 70(4):457-65.

[28] Palanisamy P, Sasikala G, Mallikaraj D, Bhuvaneshwari N, Natarajan GM. Haematological changes of fresh water food fish, Channa striata on exposure to Cleistanthus collinus suicidal plant extract. Research Journal of Pharmaceutical, Biological and Chemical Sciences. 2011; 2(2):812-6.

[29] Srivastav AK, Roy D. Effects of malachite green (Triarylmethane dye) and Pyceze (Bronopol) on the hematological parameters of a freshwater catfish Heteropneustes fossilis (Bloch). Int. J. Fish. Aquat. Stud. $2015 ; 2: 119-22$.

[30] Dutta HM, Dogra JV, Singh NK, Roy PK, Nasar SS, Adhikari S, Munshi JS, Richmonds C. Malathion induced changes in the serum proteins and hematological parameters of an Indian catfish Heteropneustes fossilis (Bloch). Bulletin of environmental contamination and toxicology. 1992; 49(1):91-7.

[31] Srivastava AK, Singh NN. Hematological changes in Heteropneustes fossilis exposure to Aldrin. Nature. 1994; 6(1):85-8.

[32] Oshode OA, Bakare AA, Adeogun AO, Efuntoye MO, Sowunmi AA. Ecotoxicological assessment using Clarias gariepinus and microbial characterization of leachate from municipal solid waste landfill. International Journal of Environmental Research.2008; 2(4).

[33] Gautam RK, Suneel K. Alteration in haematology of Channa punctatus (Bloch). Journal of Experimental Zoology, India. 2008; 11(2):309-10.
[34] Srivastava RK, Srivastava S. Cadmium (Cd) induced haematological changes in a freshwater catfish, Heteropneustes fossilis. Journal of Advanced Zoology. 2002; 23(1):23-9.

[35] Patro L. Toxicological effects of cadmium chloride on Acetyl cholinesterase activity of freshwater fish, Oreochromis mossambicus Peters. Asian J. Exp. Sci. 2006; 20(1):171-80

[36] Köprücü SŞ, Köprücü K, Ural MŞ, İspir Ü, Pala M. Acute toxicity of organophosphorous pesticide diazinon and its effects on behavior and some hematological parameters of fingerling European catfish (Silurus glanis L.). Pesticide Biochemistry and Physiology. 2006; 86(2):99-105.

[37] Figueiredo-Fernandes A, Ferreira-Cardoso JV, Garcia-Santos S, Monteiro SM, Carrola J, Matos P, Fontaínhas-Fernandes A. Histopathological changes in liver and gill epithelium of Nile tilapia, Oreochromis niloticus, exposed to waterborne copper. Pesquisa Veterinária Brasileira. 2007; 27(3):103-9.

[38] Camargo MM, Martinez CB. Histopathology of gills, kidney and liver of a Neotropical fish caged in an urban stream. Neotropical Ichthyology. 2007; 5(3):327-36.

[39] Sharma KP, Sharma S, Sharma S, Singh PK, Kumar S, Grover R, Sharma PK. A comparative study on characterization of textile wastewaters (untreated and treated) toxicity by chemical and biological tests. Chemosphere. 2007; 69(1):48-54.

[40] Olurin KB, Olojo EA, Mbaka GO, Akindele AT Histopathological responses of the gill and liver tissues of Clarias gariepinus fingerlings to herbicide, glyphosate. African Journal of Biotechnology. 2006; 5(24):2480.

[41] Ribeiro CO, Pelletier E, Pfeiffer WC, Rouleau C. Comparative uptake, bioaccumulation, and gill damages of inorganic mercury in tropical and nordic freshwater fish. Environmental Research. 2000; 83(3):286-92.

[42] Velmurugan B, Selvanayagam M, Cengiz EI, Unlu E. Histopathological changes in the gill and liver tissues of freshwater fish, Cirrhinus mrigala exposed to dichlorvos. Brazilian Archives of Biology and Technology. 2009; 52(5):1291-6.

[43] Jiraungkoorskul W, Upatham ES, Kruatrachue M, Sahaphong S, Vichasri - Grams S, Pokethitiyook P. Biochemical and histopathological effects of glyphosate herbicide on Nile tilapia (Oreochromis niloticus). Environmental Toxicology: An International Journal. 2003; 18(4):260-7. 